\title{
QUALITATIVE AND QUANTITATIVE DETERMINATION OF SECONDARY METABOLITES OF 26 MEDICINAL PLANTS FROM SOUTHEASTERN OF EGYPT
}

\author{
Rehab A. Lotfy ${ }^{1}$, Dina M. Fahmy ${ }^{1 *}$, Fatma A. Ahmed ${ }^{2}$ \\ ${ }^{1}$ Natural Products Unit, Department of Medicinal and \\ Aromatic Plants, Desert Research Center, El-Matareya, Cairo, \\ Egypt \\ ${ }^{2}$ Phytochemistry Unit, Department of Medicinal and Aromatic \\ Plants, Desert Research Center, El-Matareya, Cairo, Egypt \\ *E-mail: dmfahmy@gmail.com
}

\begin{abstract}
amples of the 26 plants for the study were freshly obtained $\checkmark$ from the southeastern of Egypt, packed in paper bags and brought to the laboratory for further processing. $70 \%$ ethanolic extracts were prepared and subjected to phytochemical analysis of their secondary metabolites, both qualitatively (alkaloids, terpenoids, tannins, saponins, flavonoids and phenolics) and quantitatively (alkaloids, phenolics and flavonoids), in addition to elemental analysis. The qualitative evaluation showed the presence of all investigated phytocompound classes in most of the studied plants. Quantitative analysis revealed that the highest phenolics content (20.44 g \%) was in Acacia tortilis Forssk. and the highest flavonoids content (14.26 g \%) was in Matthiola arabica Boiss. Zygophyllum simplex L. highly shared with $10.94 \%$ in alkaloids pool. Elemental profile for each plant was attained. The interest in the current investigation of these 26 medicinal plants was motivated by exploring new biologically active compounds resource.
\end{abstract}

Keywords: phytochemical screening, elemental analysis, secondary metabolites, quantitative analysis

Medicinal plants played a prominent role in ancient traditional medicine systems, like the Chinese, the Ayurvedic and the Egyptian traditional medicines, and are still in common use today for the treatment of various diseases. According to the World Health Organization (WHO), over $75 \%$ of people still rely on plant-based traditional medicines for primary health care in underdeveloped or developing countries (Sarker et al., 2005). This may be attributed to a deep belief that these treatments are safe because they are "natural" and fit into the image of a gentle and harmless alternative to conventional medicine. 
Phytochemicals are non-nutritive plant chemicals that have protective or disease preventive properties. They are not mandatory for humans to consume. However, it is proven that these chemicals protect plants as well as the humans eating them. Medicinal plants are competitive in their biological abilities according to their variation in phytochemical molecules such as vitamins, terpenoids, phenolic acids, lignins, tannins, flavonoids, quinones, coumarins and alkaloids.

Phytochemicals are known to possess antioxidant (Wong et al., 2009), antibacterial (Nair et al., 2005), antifungal (Khan and Wassilew, 1987), antidiabetic (Singh and Gupta, 2007 and Kumar et al., 2008a), antiinflammatory (Kumar et al., 2008b), and radioprotective activity (Jagetia et al., 2005), and due to these properties, they are largely used for medicinal purpose. Polyphenols, especially flavonoids, are of particular interest since they demonstrate a whole spectrum of biological activities (Hollman and Arts, 2001; Aruoma, 2002 and Jayaprakasam et al., 2005). Many of the phenolic compounds have been identified as powerful antioxidants (Aruoma, 2003; Bahorun et al., 2003 and Luximon-Ramma et al., 2003), cardioprotective (Bagchi et al. 2003), anticancer (Lambert and Yang, 2003). Tannins are used in medicine primarily because of their astringent properties, which are due to the fact that they react with the proteins of the layers of tissue with which they come into contact (Samuelsson, 1999).

Following the glow of the new vision to the medicinal plants and their healing potency, a search work was achieved on 26 medicinal plants obtained from the southeastern of Egypt. The ethanolic extracts of 26 medicinal plants were screened for their phytochemical constituents. The presented work attempts to create a phytochemical profile for each tested medicinal plant.

\section{MATERIALS AND METHODS}

\section{Collection of Plant Samples}

The aerial part of all plants (one sample for each species) were collected from Southeastern Egypt, Shalateen-Halayeb area during the year (2014-2015) according to (Ahmed and Lotfy, 2015). Plants used were identified and authenticated at the herbarium, Desert research center (DRC), Egypt, where their voucher specimens are deposited.

\section{Preparation of Plant Extracts}

Plant samples were collected, packed in paper bags and coded in the field. Samples were taken to the lab and processed. The aerial parts of plant materials were air-dried at room temperature and grinded to coarse powder. Twenty gram of each powdered plant material was soaked in ethanol (200 $\mathrm{ml} \times 4)$. Extracts were filtered on Whatman filter paper No. $42(125 \mathrm{~mm})$, 
collected, and concentrated under vacuum at $40^{\circ} \mathrm{C}$. The dry extracts were stored at $4^{\circ} \mathrm{C}$ for further investigation (Harborne, 1973).

\section{Phytochemical Screening}

An amount of $0.1 \mathrm{~g}$ of dry extract of each species was re-solubilized in $25 \mathrm{ml}$ of ethanol $(70 \%)$. The ethanolic extracts were used to perform the phytochemical screening by using standard methods for the detection of the following: alkaloids (Harborne, 1973), flavonoids and phenolics (Harborne et al., 1975), saponins (Frothing test) according to Kumar et al., (2009), tannins using ferric chloride reagent as described by Trease and Evans (1996) and terpenoids using Libermann-Burchard test or using Salkowiski's test (Ayoola et al., 2008).

\section{Determination of Total Flavonoids}

Total flavonoid in the ethanolic extract was estimated by the aluminum chloride colorimetric method according to Chang et al. (2002). A volume of $0.5 \mathrm{ml}$ of each sample was taken in a test tube alongside with different standard quercetin solutions. A volume of $1.5 \mathrm{ml} 95 \%$ ethanol, 0.1 $\mathrm{ml}$ of $10 \%$ aluminum chloride, $0.1 \mathrm{ml}$ of potassium acetate and $2.8 \mathrm{ml}$ of distilled $\mathrm{H}_{2} \mathrm{O}$ were added successively to each tube (The amount of sample was replaced by the same amount of $95 \%$ ethanol in blank). After incubation at room temperature for $30 \mathrm{~min}$ the absorbance of the reaction mixture was measured at $415 \mathrm{~nm}$ using Unicam UV/Vis spectrophotometer. The flavonoid concentration (g quercetin equivalent/100 g dry powder) was calculated from the standard curve.

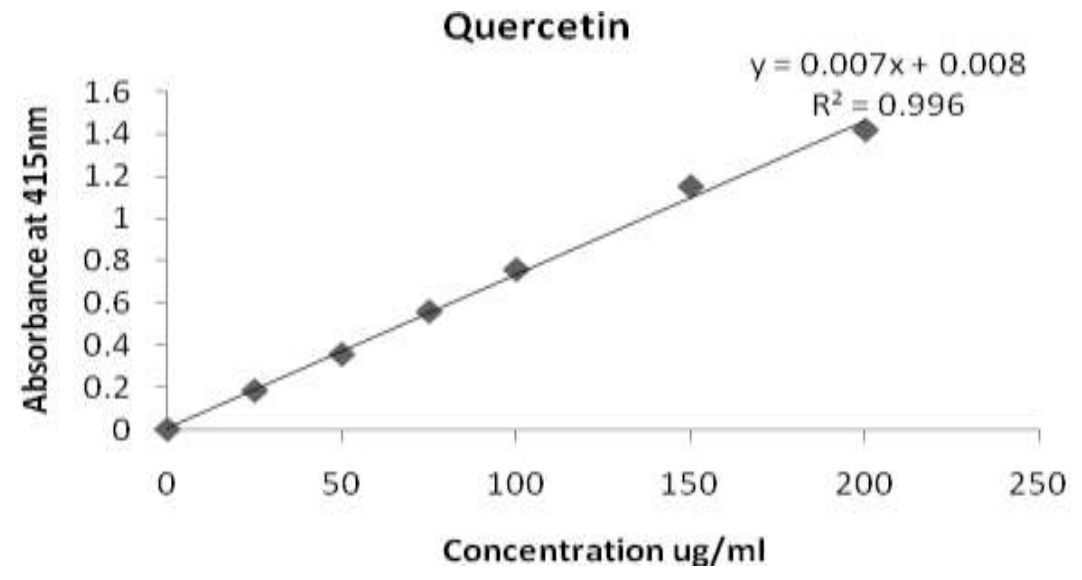

Egyptian J. Desert Res., 65, No. 2, 309-326 (2015) 


\section{Determination of Total Phenolics}

Phenolics and tannins were determined according to Makkar et al. (1993). A volume of $20 \mu \mathrm{l}$ tannin-containing extract was taken in a test tube alongside with serial concentrations of standard tannic acid. The volume was made up to $0.5 \mathrm{ml}$ with distilled water. A volume of $1.25 \mathrm{ml}$ of $20 \%$ sodium carbonate solution was added, followed by $0.25 \mathrm{ml}$ of diluted FolinCiocalteau reagent. The absorbance was recorded against blank (prepared as same as test but instead of sample, $20 \mu \mathrm{l}$ of water was added) after $40 \mathrm{~min}$ at $725 \mathrm{~nm}$ using Unicam UV/Vis spectrophotometer. The concentration of total phenolics as $\mathrm{g}$ tannic acid equivalent/100 $\mathrm{g}$ dry powder was calculated from the standard curve.

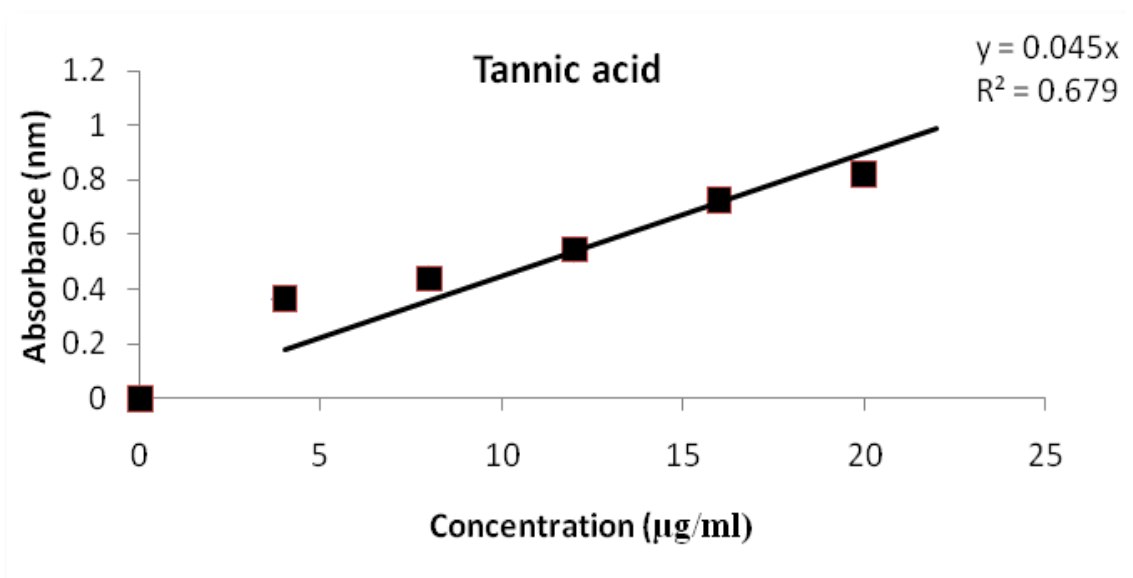

\section{Determination of Total Alkaloids}

Ethanolic extract was prepared from $2 \mathrm{~g}$ powder of each plant. The alcoholic extract was dried, dissolved in $2 \mathrm{~N} \mathrm{HCl}$, shaken and filtered. The filtrate was washed with chloroform. The acidic aqueous layer was adjusted to alkaline $\mathrm{pH}$ with ammonia to liberate alkaloidal bases. Alkaloids in alkaline aqueous layer were extracted by chloroform. The combined chloroform extracts was filtered over anhydrous sodium sulphate and evaporated under vacuum. The percentage was calculated as $w / w$ on the basis of dried plant material (Balbaa, 1986).

\section{Mineral Analysis}

One gram of each sample was digested with nitric acid: perchloric acid: sulfuric acid mixture in the ratio 9:2:1, respectively, and filtered. The filtrate was made up to $5 \mathrm{ml}$ in volumetric flask. Values of potassium and sodium were determined using a flame photometer (FP 920, PG Instruments) using $\mathrm{NaCl}$ and $\mathrm{KCl}$ as the standard (AOAC, 2012), while the filtered solution was loaded to an Inductively Coupled Argon Plasma (ICP), 6500 Duo, Thermo Scientific, England. $1000 \mathrm{mg} / \mathrm{l}$ multi-element certified 
standard solution, Merck, Germany, was used as stock solution for instrument standardization (for the rest minerals).

\section{RESULTS}

Twenty-six abundant plant species were collected from Southeastern Egypt, Shalateen-Halayeb during the year (2014-2015). The phytochemical characteristics of the 26 medicinal plants tested were summarized in table (1). The results revealed the presence of medically active compounds in the 26 plants examined. From table (1), it could be noticed that flavonoids, phenolics and tannins were present in all the examined species. Furthermore, alkaloids were present in all species but absent in Abutilon pannosum, Rumex vesicarius, Suaeda monoica and Tamarix nilotica. A weak representation of alkaloids was observed in Forsskaolea tenacissima and Forsskaolea viridis. Only fifteen species shared with their saponin and terpenoid compounds in the investigated phytocompound pool.

From the quantitative results outlined in table (2), it was observed that, the highest value of total flavonoids was detected in Matthiola arabica

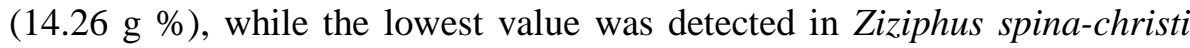
$(0.67 \mathrm{~g} \%)$. All the 26 plants contain phenolics, but in different values. The highest value was attributed to Acacia tortilis (Forssk) recording $20.44 \mathrm{~g} \%$, where the lowest value was recognized in Atriplex farinosa (Forssk.) recording $0.67 \mathrm{~g} \%$. Zygophyllum simplex shared with $10.94 \mathrm{~g} \mathrm{\%}$ in alkaloidal pool recording the highest value, while the lowest share was presented by Rhizophora mucronata with percentage of $0.02 \mathrm{~g} \%$.

Mineral analysis was directed to obtain a mineral profile for each plant. The results in table (3) showed a great variability in the element content according to plant species. Maximum accumulation of $\mathrm{Ca}, \mathrm{Fe}, \mathrm{Mg}$, $\mathrm{Zn}$, Na and $\mathrm{K}$ were in Forsskaolea tenacissima (313.70 ug/g), Cotula cinerea (28.41 ug/g), Forsskaolea tenacissima $(68.02 \mathrm{ug} / \mathrm{g})$, Zygophyllum album (28.36 ug/g), Suaeda monoica (86.00 ug/g), and Rumex vesicarius $(48.00 \mathrm{ug} / \mathrm{g})$, respectively. Minerals such as $\mathrm{Co}$ and $\mathrm{Pb}$ were having no detected concentration in the studied plants. 
Table (1). Qualitative analysis of phytochemicals in ethanolic extracts of the selected medicinal plants.

No. Plant species

Phytochemicals

Phenolics Alkaloids Flavonoids Saponins Tannins Terpenoids

$1 \quad$ Abutilon pannosum Forst. fil.

$2 \quad$ Acacia tortilis Forssk

$3 \quad$ Achillea fragrantissima Forssk.

4 Aeluropus littoralis Gouan

$5 \quad$ Atriplex farinose Forssk.

$6 \quad$ Avicennia marina Forssk.

$7 \quad$ Cotulac inerea Delile.

$8 \quad$ Crotolaria aegyptiaca Benth

$9 \quad$ Forsskaolea tenacissima $\mathrm{L}$.

$10 \quad$ Forsskaolea viridis Ehrenb. ex Webb

$\begin{array}{lllll}+ & - & + & + \\ + & + & + & +\end{array}$

11 Leptadenia pyrotechnica Forssk.

$12 \quad$ Limonium axillare Forssk

13 Matthiola Arabica Boiss.

14 Plantago afra L.

15 Reseda pruinosa Delile.

16 Rhizophora mucronata Lam.

17 Rumex vesicarius L.

18 Salvadora persica Linn

19 Senna alexandrina Mill.

20 Senna italic Mill.

\begin{tabular}{|c|c|c|c|c|c|}
\hline+ & + & + & - & + & + \\
\hline+ & + & + & + & + & + \\
\hline+ & + & + & + & + & - \\
\hline+ & + & + & - & + & + \\
\hline+ & + & + & + & + & + \\
\hline+ & + & + & + & + & - \\
\hline+ & traces & + & - & + & - \\
\hline+ & traces & + & - & + & - \\
\hline+ & + & + & - & + & + \\
\hline+ & + & + & - & + & + \\
\hline+ & + & + & - & + & - \\
\hline+ & + & + & - & + & - \\
\hline+ & + & + & - & + & - \\
\hline+ & + & + & + & + & + \\
\hline+ & - & + & + & + & + \\
\hline+ & + & + & + & + & + \\
\hline+ & + & + & + & + & + \\
\hline+ & + & + & + & + & + \\
\hline
\end{tabular}

Egyptian J. Desert Res., 65, No. 2, 299-316 (2015) 


\section{Cont. Table (1)}

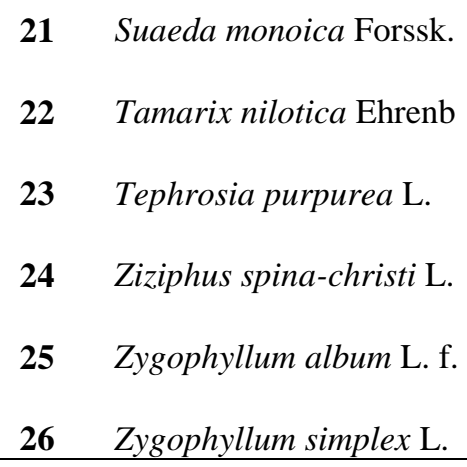

$21 \quad$ Suaeda monoica Forssk.

22 Tamarix nilotica Ehrenb

23 Tephrosia purpurea $\mathrm{L}$.

24 Ziziphus spina-christi $\mathrm{L}$.

25 Zygophyllum album L. f.

26 Zygophyllum simplex $\mathrm{L}$.

Table (2). Quantitative analysis of the selected medicinal plants.

\begin{tabular}{|c|c|c|c|c|}
\hline No. & Plant species & $\begin{array}{l}\text { Flavonoids } \\
\text { g \% (w/w) }\end{array}$ & $\begin{array}{l}\text { Alkaloids } \\
\text { g \% (w/w) }\end{array}$ & $\begin{array}{l}\text { Phenolics } \\
\text { g \% (w/w) }\end{array}$ \\
\hline 1 & Abutilon pannosum Forst. fil. & 3.69 & - & 6.50 \\
\hline 2 & Acacia tortilis Forssk. & 8.95 & 0.10 & 20.44 \\
\hline 3 & Achillea fragrantissima Forssk. & 2.59 & 0.30 & 12.22 \\
\hline 4 & Aeluropus littoralis Gouan & 0.29 & 0.43 & 0.71 \\
\hline 5 & Atriplex farinose Forssk. & 0.43 & 0.27 & 0.67 \\
\hline 6 & Avicennia marina Forssk. & 1.46 & 0.15 & 4.14 \\
\hline 7 & Cotulac inerea Delile. & 4.78 & 0.26 & 8.53 \\
\hline 8 & Crotolaria aegyptiaca Benth & 1.99 & 0.55 & 6.58 \\
\hline 9 & Forsskaolea tenacissima L. & 2.27 & - & 2.94 \\
\hline 10 & Forsskaolea viridis Ehrenb. & 12.19 & - & 12.87 \\
\hline 11 & Leptadenia pyrotechnica Forssk. & 2.27 & 0.24 & 4.07 \\
\hline 12 & Limonium axillare Forssk. & 2.26 & 0.34 & 4.77 \\
\hline 13 & Matthiola arabica Boiss. & 14.26 & 0.22 & 7.16 \\
\hline 14 & Plantago afra $\mathrm{L}$. & 2.41 & 0.24 & 3.40 \\
\hline 15 & Reseda pruinosa Delile. & 1.38 & 0.79 & 4.69 \\
\hline 16 & Rhizophora mucronata Lam. & 3.68 & 0.02 & 15.91 \\
\hline 17 & Rumex vesicarius $\mathrm{L}$. & 2.98 & - & 5.18 \\
\hline 18 & Salvadora persica Linn. & 3.84 & 0.32 & 3.83 \\
\hline 19 & Senna alexandrina Mill. & 6.25 & 0.25 & 5.52 \\
\hline 20 & Senna italic Mill. & 4.27 & 0.30 & 6.41 \\
\hline 21 & Suaeda monoica Forssk. & 1.77 & - & 6.98 \\
\hline 22 & Tamarix nilotica Ehrenb. & 2.65 & - & 5.07 \\
\hline 23 & Tephrosia purpurea L. & 6.72 & 0.22 & 8.24 \\
\hline 24 & Ziziphus spina-christi L. & 0.67 & 0.08 & 2.16 \\
\hline 25 & Zygophyllum album L.f. & 0.88 & 0.09 & 1.90 \\
\hline 26 & Zygophyllum simplex L. & 0.88 & 10.94 & 1.84 \\
\hline
\end{tabular}




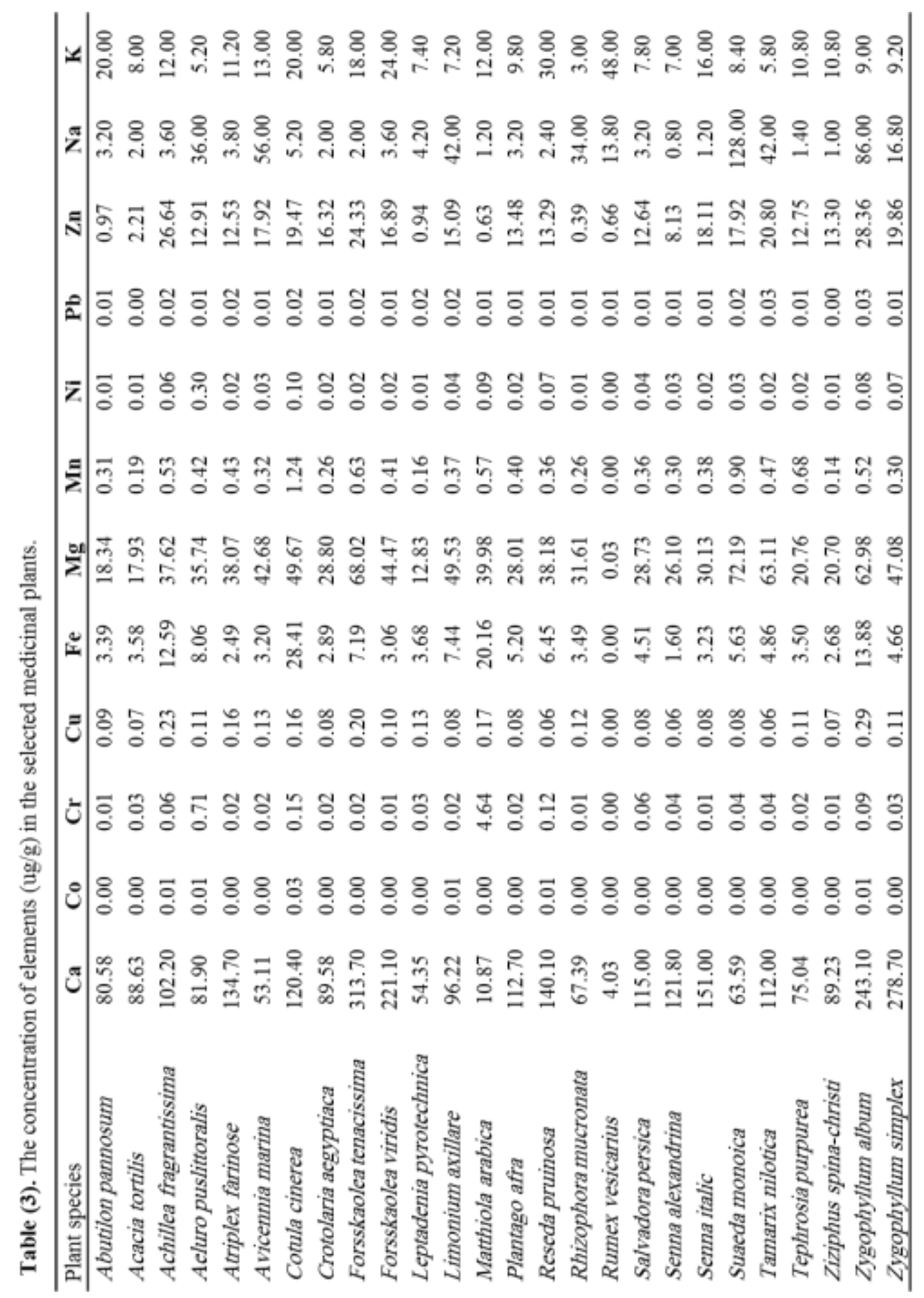

Egyptian J. Desert Res., 65, No. 2, 309-326 (2015) 


\section{DISCUSSION}

The presence of these valuable secondary metabolites and their concentrations level in the studied species may be the foundation of their therapeutic effects in the traditional medicine and accountable for many pharmacological actions. Qualitative and quantitative analysis of the 26 selected medicinal plants revealed that phytocompound pool comprises flavonoids, phenolics, alkaloids, saponins, tannins and terpenoids.

Phenolic compounds are one of the largest and most ubiquitous classes of plant secondary metabolites (Singh et al., 2007). They hold healing properties such as anti-apoptosis, antiaging, anticarcinogen, anti-inflammatory, anti-atherosclerosis, cardiovascular protection and improvement of endothelial function, besides inhibition of angiogenesis and cell proliferation activities (Han et al., 2007). Several studies have described the antioxidant properties of medicinal plants, which are rich in phenolic compounds (Brown and Rice-Evans, 1998 and Krings and Berger, 2001). Plants such Acacia tortilis (Forssk), containing high amount of phenolics (20.44 $\mathrm{g} \%$ ) and of flavonoids (8.95 g \%), predicts high effectiveness in medicinal use. Yadav et al., (2013) reported that Acacia tortilis has vast pharmacological actions such as antidiabetic, antifungal, antimalarial, treatment of dry cough and hypercholesterolemia besides, it is used as food in Kenya and food additive. Moreover, Bailey and Danin (1981) reported that, $M$. arabica (flower and stem) that hold high amount of flavonoids (14.26\%) is eaten as food by Bedouins in Saini, Egypt.

Flavonoids are hydroxylated phenolic compounds that are synthesized by plants in response to microbial infection and they have been found to be antimicrobial substances against wide array of microorganisms in vitro. Their activity is probably due to their ability to complex with extracellular and soluble proteins and to complex with bacterial cell wall (Marjorie, 1996). Flavonoids have enhanced great interest recently because of their potential beneficial effects on human health such as antiviral, anti-diabetic, anti-inflammatory, antitumor, anti-carcinogenic and anti-ageing properties (Cook and Samman 1996; Ren et al., 2003; Zhou et al., 2009 and Patra and Chua, 2010). Sharififar et al. (2009) declared that these compounds contribute in all the former biological activities via their strong antioxidant potential and free radical scavenger ability. 
The plant extracts were also revealed to contain saponins, which are known to produce inhibitory effect on inflammation (Just et al., 1998). Saponins have the property of precipitating and coagulating red blood cells. Some of the characteristics of saponins include formation of foams in aqueous solutions, hemolytic activity, cholesterol binding properties and bitterness (Sodipo et al., 2000 and Okwu, 2004).

Tannins have potent astringent properties. They are known to hasten the healing of wounds and inflamed mucous membranes. Terpenoids have been found to be useful in the prevention and therapy of several diseases, including cancer. Terpenoids are also known to possess antimicrobial, antifungal, antiparasitic, antiviral, antiallergenic, antispasmodic, antihyperglycemic, antiinflammatory and immunomodulatory properties (Wagner and Elmadfa, 2003 and Rabi and Bishayee, 2009). In addition, terpenoids can be used as protective substances in storing agriculture products as they are known to have insecticidal properties as well (Sultana and Ata, 2008).

Alkaloids have been associated with medicinal uses for centuries and one of their common biological properties is their cytotoxicity (Nobori et al., 1994). Several researchers have reported the analgesic and anti-inflammatory, antimicrobial and amoebicidal activity properties of alkaloids (Kaur and Arora, 2015). Furthermore, $\mathrm{Ng}$ et al. (2015) informed that two alkaloids (galantamine and rivastigmine) proved to have potent impact on Alzheimer's disease (AD), where US Food and Drug Administration (FDA) approved acetylcholinesterase inhibitors for AD. It is worth to mention that several alkaloids isolated from natural herbs exhibit antiproliferation and antimetastasis effects on various types of cancers both in vitro and in vivo. Alkaloids, such as camptothecin and vinblastine, have already been successfully developed into anticancer drugs (Lu et al., 2012).

Plant uptake is one of the major routes of exposure of the food chain to trace elements in the soil (Logan et al., 1997). Trace elements play an important role in the chemical, biological, metabolic, and enzymatic reactions in the living cells of plants, animals, and human beings (Hashmi et al., 2007).

It was important to determine trace elements' status for the 26 medicinal plants. It is worthy to note that many curative effects of medicinal plants used in the traditional system of medicines may be attributed to the presence of very minute quantities of trace elements. Elements, particularly essential trace elements have both curative and 
preventive task in fighting diseases such as $\mathrm{Fe}$ in anemia and iodine in goiter. In this study, the level of $\mathrm{Fe}, \mathrm{Cu}, \mathrm{Co}, \mathrm{Ni}, \mathrm{Zn}, \mathrm{Mg}, \mathrm{Mn}, \mathrm{Cr}, \mathrm{Ca}$, $\mathrm{Na}, \mathrm{K}$ and $\mathrm{Pb}$ were investigated. The deficiency of trace elements in human can occur under most life style dietary conditions. Shirin et al. (2010) mentioned that many diseases, which have been considered incurable may now possibly be treated by balancing the disequilibrium of these elements in the human body.

Comparing with the WHO standard for allowed level of $\mathrm{Cu}$ element in medicinal plants $(15 \mu \mathrm{g} / \mathrm{g})$, the results are within limit. Excessive intake of $\mathrm{Cu}$ in human may cause heamolysis and nephrotoxic effects. The continuous ingestion of copper from food may induce chronic copper poisoning in man (Olowoyo et al., 2012). Copper deficiency in human may result in hypochromic microcytic anemia, neutropenia and bone changes (Linder and Hazeg-Azam, 1996).

Fe is a vital element in human body, it acts as a catalyst and contributes in hemoglobin manufacture. It plays an important role in oxygen and electron transfer in human body (Kaya and Incekara, 2000). The level of Fe in all the plants was lower than results achieved by Shirin et al. (2010) and Jabeen et al. (2010) on other plants. For medicinal plants the WHO (2005) limits not yet been established for Fe element. Sheded et al. (2006) reported that the range of Fe in their study was between 261 to $1239 \mathrm{ppm}$ in selective medicinal plants of Egypt.

The permissible limit of $\mathrm{Cr}$ set by FAO/WHO (1984) in edible plants was $0.02 \mathrm{ug} / \mathrm{g}$. Evaluation of metal limit in the studied medicinal plants with those proposed by FAO/WHO (1984) leads to conclusion that all plants accumulate $\mathrm{Cr}$ within limit, except $M$. arabica, A. littoralis, $R$. pruinosa and $C$. cinerea. Chronic exposure to $\mathrm{Cr}$ may result in liver, kidney and lung damage (Zayed and Terry, 2003). In medicinal plants, permissible limits for $\mathrm{Cr}$ set by Canada, were $2 \mathrm{ppm}$ in raw medicinal plant material and $0.02 \mathrm{mg} /$ day in finished herbal products (WHO, 2005). Cr specific recommendations are depending on age and gender, its values ranges from $0.2 \mu \mathrm{g} / \mathrm{g}$ to $5.5 \mu \mathrm{g} / \mathrm{g}$ for infants under the age of 12 months (Hamrick and Counts, 2008).

In comparison with metal limit in the studied medicinal plants with those proposed by FAO/WHO (1984), it is found that all the plants accumulates $\mathrm{Zn}$ in normal pattern, considering a report submitted by Ajasa et al., (2004) the value of $\mathrm{Zn}$ in agricultural 
products should not exceed $200 \mu \mathrm{g} / \mathrm{g}$. Zn has been reported to have beneficial effects on the atherosclerotic patients as compared to normal (controls). Subnormal plasma $\mathrm{Zn}$ level has been reported in patients with atherosclerosis (Ripa and Ripa, 1994). Zn may be correlated with anticancer property, as it is required in growth and proliferation of normal cells (FransKok et al., 1988) as the enzymes involved in the nucleic acid synthesis are $\mathrm{Zn}$ dependent (CaballeroGeorge et al., 2001). Calcium, magnesium and manganese exhibited low concentration all over the studied plants, when compared to data obtained by Jabeen et al. (2010).

The results obtained in this study suggest the identified phytochemical classes may be considered as a valuable reservoir of bioactive compounds of significant medicinal worth.

\section{CONCLUSION}

All in all, qualitative and quantitative screening of the selected 26 medicinal plants clearly reveals that the major classes of phytocompounds are present. Hence, the examined plant extracts could be more investigated for their therapeutic capabilities, considering their traditional healing use in the area of study. This work explored a new pool of natural products from a phyto-origin that can be a promising resource for the pharmaceutical industry. It is worth to conduct more search work on these plants.

\section{REFERENCES}

A.O.A.C. (2012). In "Official Methods of Analysis of AOAC International, Association of Official Analytical Chemists", 19th ed., Washington, D.C.

Ahmed, F.A. and R.A. Lotfy (2015). Phytochemical evaluation of some selected medicinal plants growing wildly in Southeastern Egypt. Middle East Journal of Applied Sciences, 5 (4): 1239-1246.

Ajasa, A.M.O., M.O. Bello, A.O. Ibrahim, I.A. Ogunwande and N.O. Olawore (2004). Heavy trace metals and macronutrients status in herbal plants of Nigeria. Food Chemistry, 85: 67-71.

Aruoma, O.I. (2002). Neuroprotection by dietary antioxidants: new age of research. Nahrung Food, 46: 381-382.

Aruoma, O.I. (2003). Methodological considerations for characterizing potential antioxidant actions of bioactive components in plant foods. Mutation Research, 523/524: 9-20.

Ayoola, G.A., H.A.B. Coker, S.A. Adesegun, A.A. Adepoju-Bello, $\quad$ K. Obaweya, E.C. Ezennia and T.O. Atangbayila (2008). Phytochemical screening and antioxidant activities of some selected

Egyptian J. Desert Res., 65, No. 2, 309-326 (2015) 
medicinal plants used for malaria therapy in South Western Nigeria. Tropical Journal of Pharmaceutical Research, 7: 1019-1024.

Bagchi, D., C.K. Sen, S.D. Ray, D.K. Das, M. Bagchi, H.G. Preuss and J.A. Vinson (2003). Molecular mechanisms of cardioprotection by a novel grape seed proanthocyanidin extract. Mutation Research, 523/524: 87-97.

Bahorun, T., E. Aumjaud, H. Ramphul, M. Rycha, A. Luximon-Ramma, F. Trotin and O.I. Aruoma (2003). Phenolic constituents and antioxidant capacities of Crataegus monogyna (hawthorn) callus extracts. Nahrung Food, 47: 191-198.

Bailey, C. and A. Danin (1981). Bedouin plant utilization in Sinai and the Negev. Economic Botany, 35 (2): 145-162.

Balbaa, S.I. (1986). In "Chemistery of Crude Drugs-Libratory Manual". Faculty of Pharmacy, Cairo Univ., 195 pp.

Brown, J.E. and C.A. Rice-Evans (1998). Luteolin rich artichoke extract protects low density lipoprotein from oxidation in vitro. Free Radical Research, 29: 247-255.

Caballero-George, C., P.M.L. Vanderheyden, P.N. Solis, L. Proters, A.A. Shahat, M.P. Gupta, G. Vanquelin and A.J. Vlietinck (2001). Biological screening of selected medicinal Panamanian plants by radioligand-binding techniques. Phytomedicine, 8 (1): 59-70.

Chang, C.C., M.H. Yang, H.M. Wen and J.C. Chern (2002). Estimation of total flavonoid content in propolis by two complementary colorimetric methods. Journal of Food and Drug Analysis, 10: 178182.

Cook, N.C. and S. Samman (1996). Flavonoids: chemistry, metabolism, cardioprotective effects and dietary sources. Nutritional Biochemistry, 7: 66-76.

FAO/WHO (1984). In "Contaminants". Codex Alimentarius, vol. XVII, Edition 1. FAO/WHO, Codex Alimentarius Commision, Rome.

FransKok, J., M. Cornelia Vanduijn, A. Hofman, B. Gigsbert, V. Voet, A. Fred De Wolf and J. Kok (1988). Serum copper and zinc and the risk of death from cancer and cardiovascular disease. Epidemiology, 128: 352-359.

Hamrick, I. and S.H. Counts (2008). Vitamin and mineral supplements. Wellness and Prevention, 35: 729-747.

Han, X., T. Shen and H. Lou (2007). Dietary polyphenols and their biological significance. International Journal of Molecular Sciences, 8 (9): 950-988.

Harborne, J.B. (1973). In "Phytochemicals Methods". Chapman and Hill, London.

Harborne, J.B., T.J. Mabery and H. Mabry (1975). In "The Flavonoids". Chapman and Hall, London. 1204 pp. 
Hashmi, D.S., S. Ismail and G.H. Shaikh (2007). Assessment of the level of trace metals in commonly edible vegetables locally available in the markets of Karachi city. Pakistan Journal of Botany, 39: 747-751.

Hollman, P.C.H. and I.C.W. Arts (2001). Flavonoids, flavones and flavonols - nature, occurrence and dietary burden. Journal of Science Food and Agriculture, 80: 1081-1093.

Jabeen, S., M.T. Shah, S. Khan and M.Q. Haya (2010). Determination of major and trace elements in ten important folk therapeutic plants of Haripur basin. Pakistan. Journal of Medicinal Plants Research, 4: 559-566.

Jagetia, G.C., M.S. Baliga and P. Venkatesh (2005). Influence of seed extract of Syzygium cumini (Jamun) on mice exposed to different doses of $\gamma$-radiation. Journal of Radiation Research, 46 (1): 59-65.

Jayaprakasam, B., S.K. Vareed, L.K. Olson and M.G. Nair (2005). Insulin secretion by bioactive anthocyanins and anthocyanidins present in fruits. Journal of Agriculture and Food Chemistry, 53: 28-31.

Lu, J., J. Bao, X. Chen, M. Huang and Y. Wang (2012). Alkaloids isolated from natural herbs as the anticancer agents. Evidence-Based Complementary and Alternative Medicine, 2012: 1-12.

Just, M.J., M.C. Recio, R.M. Giner, M.U. Cueller, S. Manez, A.R. Billia and J.L. Rios (1998). Antiinflammatory activity of unusual lupine saponins from Bupleurum fruticescens. Planta Medica, 64: 404-407.

Kaur, R. and S. Arora (2015). Alkaloids-important therapeutic secondary metabolites of plant origin. Journal of Critical Reviews, 2 (3): 1-8.

Kaya, I. and N. Incekara (2000). Contents of some wild plants species consumed as food in Aegean region. Journal of Turkish Weed Science, 3: 56-64.

Khan, M. and S.W. Wassilew (1987). In "Natural Pesticides from the Neem Tree and Other Tropical Plants". Schmutterer, H. and K.R.S. Asher (Eds.), Digitalverlag GmbH, Germany, p. 645-650.

Krings, U. and R.G. Berger (2001). Antioxidant activity of roasted foods. Food Chem., 72: 223-229.

Kumar, A., R. Ilavarasan, T. Jayachandran, M. Deecaraman, P.Aravindan, N. Padmanabhan and M.R.V. Krishan (2008a). Anti diabetic activity of Syzygium cumini seed and its isolate compounds against streptozotocin induced diabetic rats. Journal of Medicinal Plants Research, 2 (9): 246-249.

Kumar, A., R. Ilavarasan, T. Jayachandran, M. Deecaraman, M.R. Kumar, P. Aravindan, N. Padmanabhan and M.R.V. Krishan (2008b). Antiinflammatory activity of Syzigium cumini seed. African Journal of Biotechnology, 7 (8): 941-943.

Kumar, A., R. Ilavarasn, T. Jayachandran, M. Decaraman, P. Aravindhan N. Padmanaban and M.R.V. Krishnan (2009). Phytochemicals investigation on a tropical plant Syzygium cumini from 
Kattuppalayam, Erode District, Tamil Nadu, South India. Pakistan Journal of Nutrition, 8: 83-85.

Lambert, J.D. and C.S. Yang (2003). Mechanisms of cancer prevention by tea constituents. American Society for Nutritional Sciences, 133: 3262S-3267S.

Linder, M.C. and M. Hazeg-Azam, (1996). Copper biochemistry and molecular biology. American Journal of Clinical Nutrition, 63 (5): 797S- 811S.

Logan, T.J., L.E. Goins and B.J. Lindsay (1997). Field assessment of trace element uptake by six vegetables from N-Viro Soil. Water Environment Research, 69: 28-33.

Luximon-Ramma, A., T. Bahorun and A. Crozier (2003). Antioxidant actions and phenolic and vitamin $\mathrm{C}$ contents of common Mauritius exotic fruits. Journal of Science Food and Agriculture, 83: 496-502.

Makkar, H.P.S., M. Bluemmel, N.K. Borowy and K. Becker (1993). Gravimetric determination of tannins and their correlations with chemical and protein precipitation methods. Journal of Science Food and Agriculture, 61:161-165.

Marjorie, C. (1996). Plant products as antimicrobial agents. Clincal Microbiology Reviews, 12: 564-582.

Nair, R., T. Kalariya and C. Sumitra (2005). Antibacterial activity of some selected Indian medicinal flora. Turkey Journal of Biology, 29: 4147.

Ng, Y.P., T.C. Tsun Or, and N.Y. Ip (2015). Plant alkaloids as drug leads for Alzheimer's disease. Neurochemistry international, 89: 260-270.

Nobori, T., K. Miurak, D.J. Wu, L.A. Takabayashik and D.A. Carson (1994). Deletion of cyclin-dependent kinase-4 inhibitor gene in multiple human cancers. Nature, 46: 753-756.

Okwu, D.E. (2004). Phytochemicals and vitamin content of indigenous species of southeastern Nigeria. Journal of Sustainable Agriculture and the Environment, 6 (1): 30-37.

Olowoyo, J.O., O.O. Okedeyi, N.M. Mkolo, G.N. Lion and S.T.R. Mdakane (2012). Uptake and translocation of heavy metals by medicinal plants growing around a waste dump site in Pretoria. South Africa South African Journal of Botany, 78: 116-121.

Patra, J.C. and B.H. Chua (2010). Artificial neutral network-based drug design for diabetes mellitus using flavonoids. Journal of Computational Chemistry, 32: 555- 567.

Rabi, T. and A. Bishayee (2009). Terpenoids and breast cancer chemoprevention. Breast Cancer Res Treat, 115: 223-239.

Ren, W., Z. Qiao, H. Wang, L. Zhu, L. Zhang (2003). Flavonoids: promising anticancer agents. Medicinal Research Reviews, 23: 519-534.

Ripa, S. and R. Ripa (1994). Zinc and atherosclerosis. Minerva Medica, 85 (12): 647-654. 
Samuelsson, G. (1999). In "Drugs of Natural Origin". Swedish Pharmaceutical Press, Sweden.

Sarker, S.D., Z. Latif and A.I. Gray (2005). In "Natural Products Isolation: An Overview". Sarker, S.D., Z. Latif and A.I. Gray (Eds.). Natural Products Isolation, $2^{\text {nd }}$ Edition. Humana Press, New Jersey.

Sharififar, F., G. Dehghn-Nudeh and M. Mirtajaldini (2009). Major flavonoids with antioxidant activity from Teucrium polium. Food Chemistry, 112: 885-888.

Sheded, G.M., I.D. Pulford and I.A. Hamed (2006). Presence of major and trace elements in seven medicinal plants growing in the SouthEastern Desert, Egypt. Journal of Arid Environments, 66: 210-217.

Shirin, K., S. Imad, S. Shafiq and K. Fatima (2010). Determination of major and trace elements in the indigenous medicinal plant Withania somnifera and their possible correlation with therapeutic activity. Journal of Saudi Chemical Society, 14: 97-100.

Singh, N. and M. Gupta (2007). Effect of ethanolic extract of Syzygium cumini seed powder on pancreatic islets of alloxen diabetic rats. Indian Journal of Experimental Biology, 45: 861-867.

Singh, R., S.K. Singh and S. Arora (2007). Evaluation of antioxidant potential of ethyl acetate extract/fractions of Acacia auriculiformis A. Cunn. Food and Chemical Toxicology, 45: 1216-1223.

Sodipo, O.A., J.A. Akiniyi and J.U. Ogunbamosu (2000). Studies on certain characteristics of extracts of bark of Pansinystalia macruceras (K schemp) picrre Exbeille. Global Journal of Pure Applied Sciences, 6: 83-87.

Sultana, N. and A. Ata (2008). Oleanolic acid and related derivatives as medicinally important compounds. Journal of Enzyme Inhibition and Medicinal Chemictry, 23: 739-756.

Trease, G.E. and W.C. Evans (1996). In "Pharmacognosy". Alden Press, Oxford, p. 213-232.

Wagner, K.H. and I. Elmadfa (2003). Biological relevance of terpenoids: overview focusing on mono-di and tetraterpenes. Annals of Nutrition and Metabolism, 47: 95-106.

WHO (2005). In "Quality Control Methods for Medicinal Plant Materials". Revised, Geneva.

Wong, S.K., Y.Y. Lim and E.W.C. Chan (2009). Antioxidant properties of Hibiscus species variation, altitudinal change costal influence and floral colour change. Journal of Tropical Forest Science, 21: 307315.

Yadav, P., R. Kant and P. Kothiyal (2013). A Review on Acacia tortilis. International Journal of Pharmaceutical and Phytopharmacological Research, 3 (2): 93-96

Zayed, A.M. and N. Terry (2003). Chromium in the environment: factors affecting biological remediation. Plant Soil, 249: 139-156.

Egyptian J. Desert Res., 65, No. 2, 309-326 (2015) 
Zhou, T., D. Luo, X. Li and Y. Luo (2009). Hypoglycaemic and hypolipidemic effects of flavonoids from lotus (Nelum bonuficera) leaf in diabetic mice. Journal of medicinal Plants Research, 3: 290293.

Egyptian J. Desert Res., 65, No. 2, 309-326 (2015) 


\title{
التقدير الكمي والنوعي لمركبات الأيض الثانوية ل 7 ب نبات طبى تم جمعها من جنوب شرق مصر
}

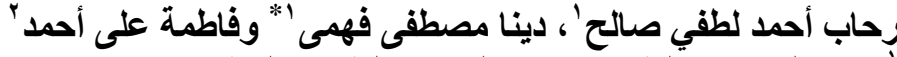

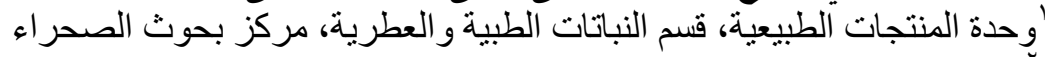

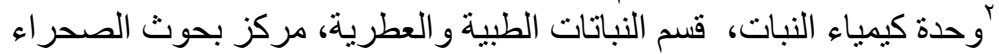

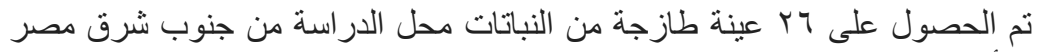

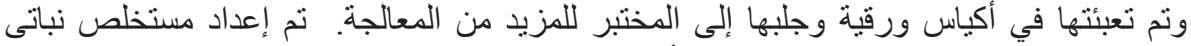

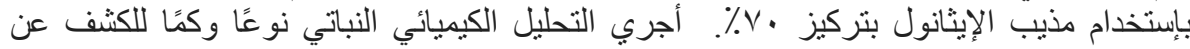

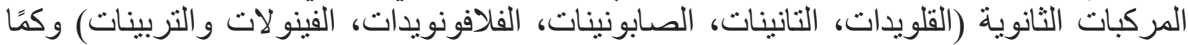

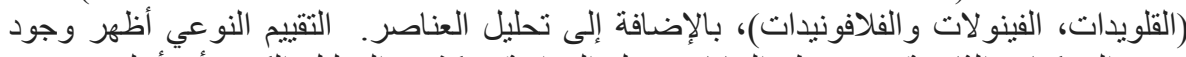

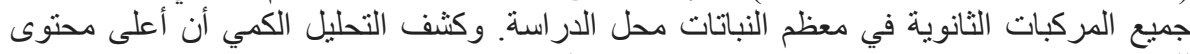

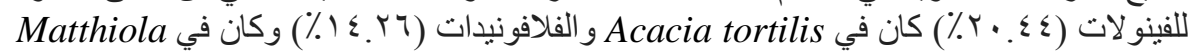

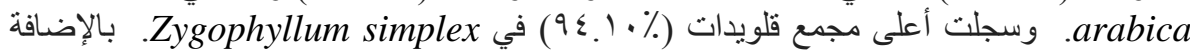

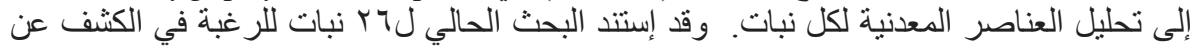
مصدر جديد لمركبات فعالة بيولوجيًا . ملئات. 